\title{
ARTICLE
}

Received 17 Apr 2014 | Accepted 28 Jul 2014 | Published 11 Sep $2014 \quad$ DOI: 10.1038/ncomms5823

\section{Chemomechanics of salt damage in stone}

\author{
Robert J. Flatt ${ }^{1,2}$, Francesco Caruso ${ }^{1}$, Asel Maria Aguilar Sanchez ${ }^{1} \&$ George W. Scherer ${ }^{3}$
}

Many porous materials are damaged by pressure exerted by salt crystals growing in their pores. This is a serious issue in conservation science, geomorphology, geotechnical engineering and concrete materials science. In all cases, a central question is whether crystallization pressure will cause damage. Here we present an experiment in which the crystallization pressure and the pore saturation are varied in a controlled way. We demonstrate that a strain energy failure criterion can be used to predict when damage will occur. The experiment considered is the most widely used means to study the susceptibility to salt crystallization, so quantification of this test has far-reaching implications.

\footnotetext{
${ }^{1}$ Physical Chemistry of Building Materials, Institut für Baustoffe, ETH Zürich, HIF E11, B60.2 and E22.2, Stefano-Franscini-Platz 3, Zurich 8093, Switzerland. 2 Sika Technology AG, Corporate Research, Tüffenwies 16, Zurich 8048, Switzerland. ${ }^{3}$ Department of Civil and Environmental Engineering, E319 Engineering Quad, Princeton University, Princeton, New Jersey 08544, USA. Correspondence and requests for materials should be addressed to R.J.F. (email: flattr@ethz.ch).
} 
T he crystallization pressure exerted by salts growing in porous hosts plays a major role in the weathering of materials, in both the natural and built environment. While this was recognized long ago in geomorphology ${ }^{1,2}$ and conservation science ${ }^{3-7}$, it has only recently emerged in concrete science as the most convincing explanation for sulfate $\operatorname{attack}^{8-10}$ and in geotechnical engineering for the floor heave of anhydrite-containing rock formations ${ }^{11}$. In the latter case, the most dramatic situation was a geothermal drilling through anhydrite-bearing rock formations that opened access for water to convert anhydrite to gypsum. In the neighbouring town, this resulted in a ground uplift of $\sim 26 \mathrm{~cm}$ and differential movements causing serious cracking in many buildings ${ }^{12}$. The same process also poses severe issues in tunnelling and mining, causing some tunnels to be periodically closed for rehabilitation because of excessive floor heave $\mathrm{e}^{13}$.

The subject of crystallization pressure has been driven by geomorphology ${ }^{14-16}$, where it is considered to play an important role in the shaping of landscapes, both on Earth ${ }^{17}$ and Mars ${ }^{18-20}$. However, it is in conservation science that the consequences of crystallization pressure are most feared because of their impact on monuments, such as the Pharaonic constructions in Luxor ${ }^{21}$, the carved city of Petra ${ }^{22,23}$ and the medieval city of Rhodes ${ }^{24}$. Crystallization pressure is even more devastating for wall paintings because of the rapid irreversible damage it can cause to works such as Michelangelo's frescoes in the Sistine Chapel ${ }^{25}$, the tomb of Nefertari ${ }^{26,27}$ or prehistoric rock art such as the Albarracin Cultural Park ${ }^{28}$, to name only a few. Figure 1 shows three different examples of the devastating action exerted by salts.

Soluble salts accumulate in building materials over years, either because of capillarity, aerosol deposition or reactions of the stone with atmospheric pollutants. It is under specific microclimate conditions that significant crystallization pressures may develop. Research on crystallization pressure has therefore been addressed from quite diverse disciplines that have been mutually enriched, particularly over the past years with their common striving to understand the microscopic origin of weathering processes ${ }^{29}$. This has led to the consensus that salts growing under confined and supersaturated conditions exert crystallization pressure $^{4,16,30,31}$ against their porous hosts, subjecting them to tensile stresses. These are particularly damaging for materials with low tensile strength, such as stone (rock), bricks, rammed earth or concrete ${ }^{31}$. However, while much progress has been made in understanding microscale phenomena, a major challenge still remains: predicting under which conditions damage may occur.
To address this issue, we examine the experiment most broadly used to study the impact of salt crystallization on materials $\mathrm{s}^{7,32-34}$ Initially proposed in 1828 (ref. 35), it has undergone minor modifications but continues to rely on cycles of impregnation and drying with a solution containing sodium sulfate, the most devastating salt known ${ }^{36}$.

\section{Results}

Sodium sulfate and its damaging nature. Samples are damaged during impregnation (Fig. 2) because of a phase change from the anhydrate present in the dry state (thenardite, $\mathrm{Na}_{2} \mathrm{SO}_{4}$ ) to the decahydrate present in the wet state (mirabilite, $\mathrm{Na}_{2} \mathrm{SO}_{4} \cdot 10 \mathrm{H}_{2} \mathrm{O}$ ). Thenardite dissolves during impregnation, which creates a high supersaturation with respect to mirabilite that makes it possible for mirabilite to exert a high crystallization pressure during its growth ${ }^{37-41}$. No damage is observed during the drying phase ${ }^{7}$.

Sodium sulfate can crystallize in at least eight different crystalline phases. At $20^{\circ} \mathrm{C}$, two are stable and three are metastable. The stable phases are mirabilite (or Glauber's salt) and thenardite (phase $\mathrm{V}$ ). The metastable phases are a heptahydrate, $\mathrm{Na}_{2} \mathrm{SO}_{4} \cdot 7 \mathrm{H}_{2} \mathrm{O}$, and two other anhydrous ones (phases III and IV), $\mathrm{Na}_{2} \mathrm{SO}_{4}$. Anhydrous phases I and II exist only at higher temperatures $\left(>270\right.$ and $>225^{\circ} \mathrm{C}$, respectively), whereas the octahydrate, $\mathrm{Na}_{2} \mathrm{SO}_{4} \cdot 8 \mathrm{H}_{2} \mathrm{O}$, is formed under highpressure conditions ${ }^{42-45}$.

Until relatively recently, most literature on the subject focused on the two stable phases and generally overlooked the heptahydrate, often stated to form only under laboratory conditions. Experimental investigations by NMR have, however, shown that this is the phase that forms most readily when samples are cooled, and that it persists unless the temperature is brought down close to $0^{\circ} \mathrm{C}$ (refs 45,46 ).

Some studies had suggested that the heptahydrate has very low solid-liquid interfacial energies and is thus incapable of generating high crystallization pressures ${ }^{47,48}$. While these statements may be somewhat revised, they remain in general agreement with more recent work by the same group that measured sample dilation during a cooling sequence that formed first the heptahydrate and then the decahydrate ${ }^{40,45}$. These results showed that the most important strains were suffered when mirabilite was formed. Such results agree with independent experiments following different experimental protocols ${ }^{49,50}$

In the later case, it was also shown that the sample deformation could be quantitatively related to the thenardite equilibrium
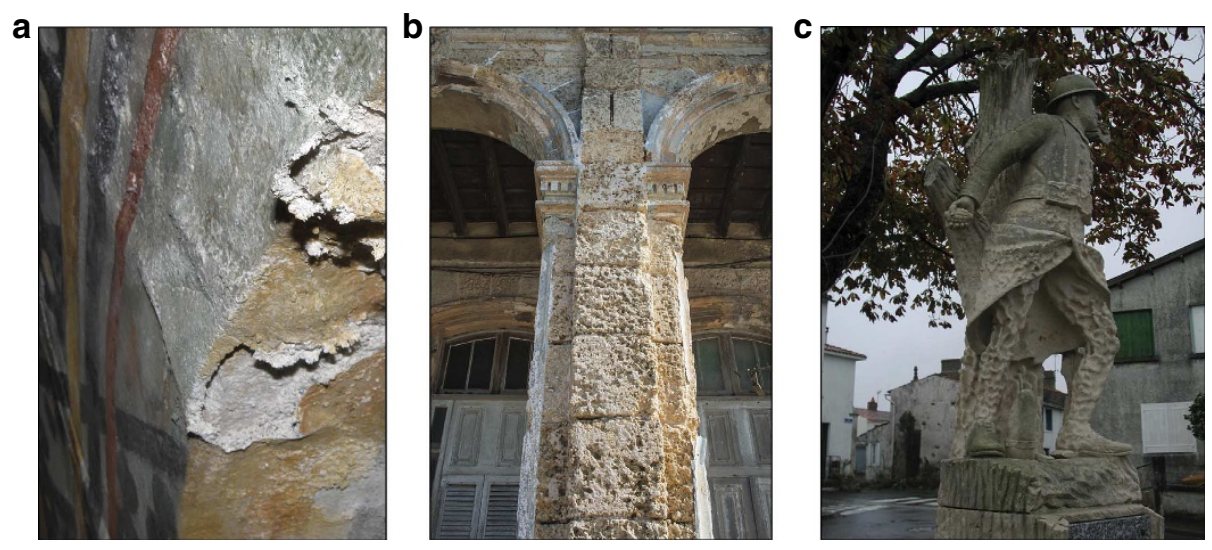

Figure 1 | Examples of the devastating action exerted by salts. (a) Painted frame of a window in the Valère Basilica in Sion, VS (Switzerland). (b) A column in a building on the Malecón in Havana (Cuba). (c) A statue in La Rochelle (France). Photo a is courtesy of F. Girardet. Photo b is property of the authors. Photo $\mathrm{c}$ is by R. van Hees. 

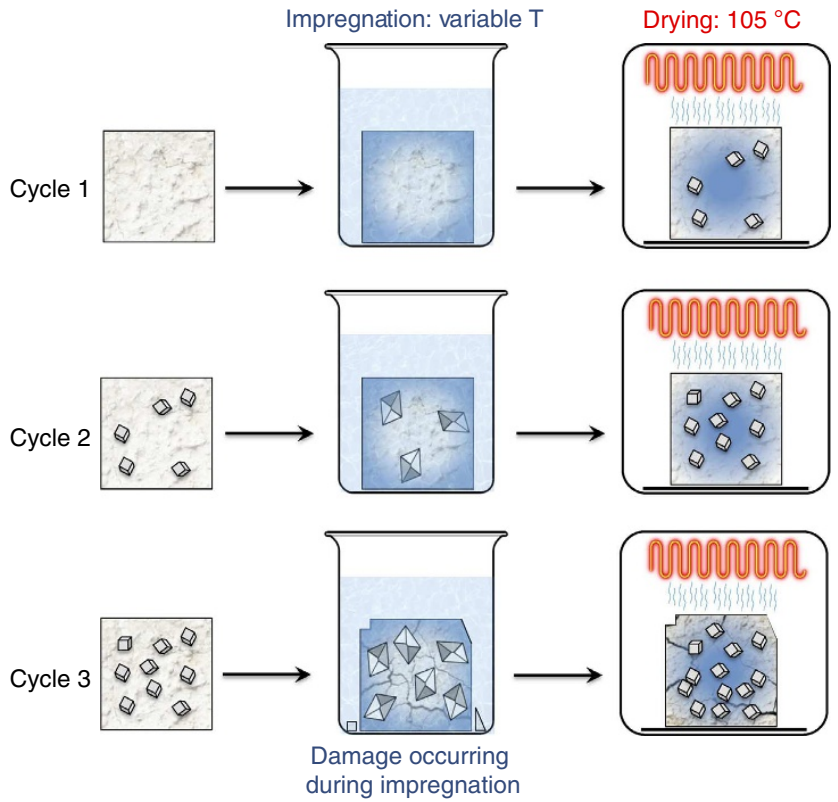

Figure 2 | Scheme of the sodium sulphate experiment. In the first cycle, the stone fills with sodium sulfate solution. During the drying, sodium sulfate crystallizes as thenardite (cubes). In the subsequent cycle, thenardite converts to mirabilite (octahedrons) through a dissolutionprecipitation process made possible by the ingress of sodium sulfate solution. The solution concentration and temperature, as well as the stone strength, determine at which cycle this process will eventually lead the corresponding crystallization pressure to cause damage (mass loss). In this specific example, this is shown already in the 3rd cycle.

hypothesis. This states that, provided that thenardite is available in the system when mirabilite is formed, then the solution concentration can be determined by the solubility of thenardite ${ }^{38,39}$. With this it is possible to determine the supersaturation with respect to mirabilite and calculate the crystallization pressure.

In our analysis of the sodium sulfate test, we used this hypothesis. In support of this choice, it should also be mentioned that there is presently only one study (using hard synchrotron $\mathrm{X}$-rays) directly examining which phase forms during the impregnation cycle ${ }^{40}$.

Thermodynamic control over crystallization pressure. By carrying out this experiment at different impregnation temperatures $\left(3,10,20\right.$ and $\left.25^{\circ} \mathrm{C}\right)$, the crystallization pressure and, consequently, the severity of the damage can be varied ${ }^{32}$. Figure 3 shows that samples initially gain mass as they accumulate salt and then lose mass as they are damaged.

Mass loss begins after fewer cycles at low temperatures because the solubility difference between mirabilite and thenardite is greatly increased, which raises the supersaturation ${ }^{38}$. The corresponding crystallization pressure is ${ }^{41}$ :

$$
\Delta P_{\mathrm{C}}=\frac{R T}{\bar{v}_{\mathrm{M}}}\left(K_{\mathrm{sp}, \mathrm{T}}-K_{\mathrm{sp}, \mathrm{M}}+10 \ln \left(\frac{R H_{\mathrm{sat}, \mathrm{T}}}{100}\right)\right)
$$

where $R$ is the gas constant, $T$ is the absolute temperature, $\bar{v}_{M}$ is the molar volume of mirabilite. $K_{\mathrm{sp}, \mathrm{T}}$ and $K_{\mathrm{sp}, \mathrm{M}}$ are the thermodynamic solubility products of thenardite and mirabilite, respectively. $R H_{\mathrm{sat}, \mathrm{T}}$ is the deliquescence relative humidity of thenardite and is determined from the water activity in a nonideal solution calculation using Pitzer coefficients suited for particularly high concentrations ${ }^{41}$.
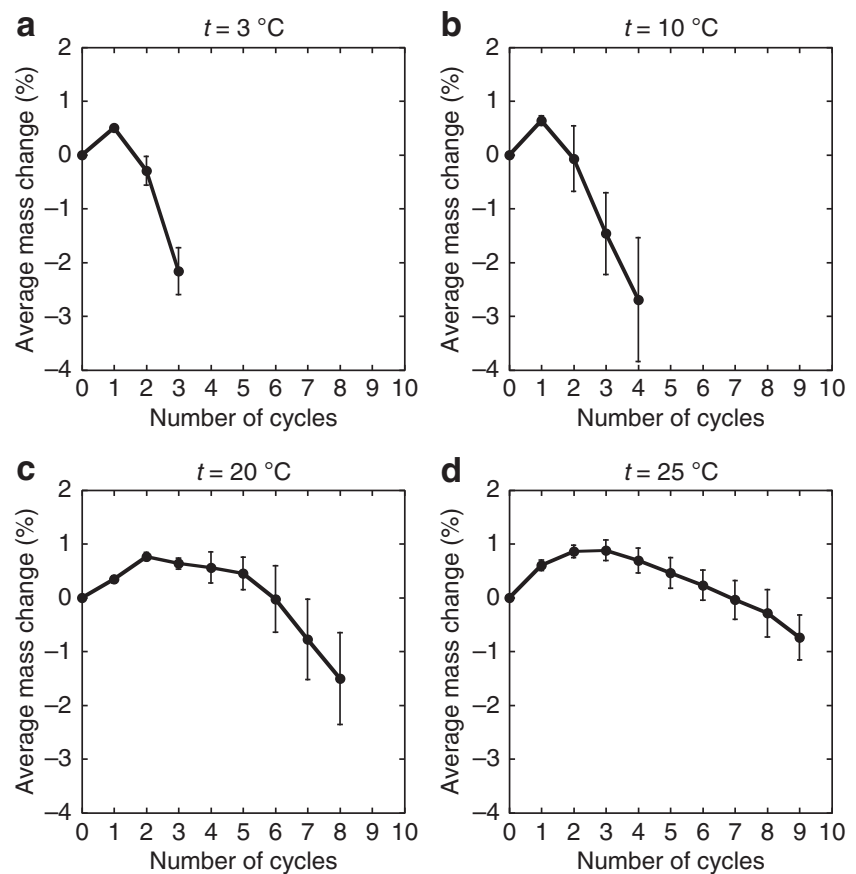

Figure 3 | Mass change of Portland limestone samples along cycles of sodium sulfate tests. The tests were performed at 3 (a), 10 (b), 20 (c) and $25^{\circ} \mathrm{C}(\mathbf{d})$ with a $6.1 \%(\mathrm{w} / \mathrm{w})$ aqueous solution. The error bars correspond to one s.d. Six samples were used for the tests at 10, 20 and $25^{\circ} \mathrm{C}$, and eight were used for those at $3^{\circ} \mathrm{C}$.

Poro-mechanical stress analysis and damage criterion. With Equation (1), it is possible to quantify the variation of crystallization pressure with temperature (Supplementary Fig. 1). However, the corresponding stress is only felt at the pore scale ${ }^{16}$ and a macroscopic tensile stress must be calculated to assess possible damage to the porous host ${ }^{8,51}$. For this, a poromechanic approach is used ${ }^{51}$, assuming that mirabilite is homogeneously distributed throughout the sample. Averaging the stress over a representative volume element gives the macroscopic tensile stress, $\sigma^{*}$ :

$$
\sigma^{*}=\sigma_{\mathrm{r}} b S_{\mathrm{c}}
$$

where $b$ is the Biot coefficient, $S_{\mathrm{c}}$ is the volume fraction of the pore space filled with crystals and $\sigma_{\mathrm{r}} \cong \Delta P_{\mathrm{C}}$ is the radial compressive stress $^{31}$. For Portland limestone, a Biot's coefficient of $0.74 \pm 0.03$ is obtained for a porosity of $20 \pm 1 \%$ and the relation proposed by Fabre and Gustkiewicz ${ }^{52}$ for limestones. Increasing the number of cycles, $i$, increases $S_{\mathrm{c}}$ as:

$$
S_{\mathrm{c}, i}=\frac{\bar{v}_{\mathrm{T}}}{\bar{v}_{\mathrm{M}}}\left(1-\left(1-\bar{v}_{\mathrm{T}} \frac{c_{\mathrm{Na}_{2} \mathrm{SO}_{4}}}{M_{\mathrm{T}}}\right)^{i}\right)
$$

where $\bar{v}_{\mathrm{T}}$ is the molar volume of thenardite, $M_{\mathrm{T}}$ is the molar mass of thenardite and $c_{\mathrm{Na}_{2} \mathrm{SO}_{4}}$ is the concentration of sodium sulfate in the solution expressed in $\mathrm{g} \mathrm{ml}^{-1}$. At a concentration of $6.1 \%(\mathrm{w} /$ $\mathrm{w}$ ), full saturation is reached between the 11th and the 12th cycles, regardless of the stone porosity (Supplementary Fig. 2). A full derivation of Equation (3) is presented in Supplementary Note 1.

Equations (1-3) quantify the increase in stresses with decreasing temperature and increasing number of cycles. Maximum values are reached in cycle 12 when the samples completely filled with mirabilite (Supplementary Fig. 3). Using a strain energy criterion, the material is expected to fail if $\sigma^{*}$ exceeds a critical stress ${ }^{53}: \sigma_{\mathrm{C}}^{*}=\sigma_{\mathrm{T}} / \sqrt{3(1-2 v)}$, where $v \approx 0.26$ 


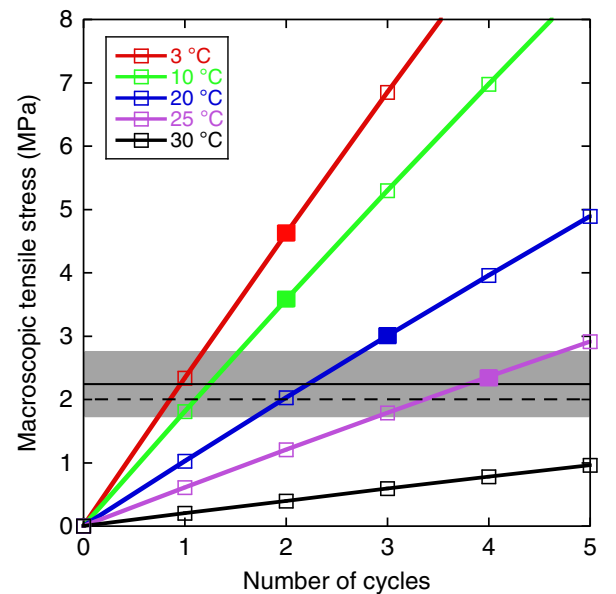

Figure 4 | Evolution of the predicted macroscopic tensile stress along cycles of impregnation and drying. In each series, the filled symbol indicates the cycle number at which $50 \%$ of the samples have lost mass. The dashed line is the maximum stress that could be reached at $30^{\circ} \mathrm{C}$, a temperature at which no damage was observed ${ }^{32}$. The continuous horizontal line is the critical macroscopic tensile stress as calculated from the average value resulting from the uniaxial tensile strength tests, carried out on 6 samples. The grey-shaded band indicates that value \pm one s.d.

(ref. 54) is Poisson's ratio and $\sigma_{\mathrm{T}}$ is the tensile strength $(2.7 \pm 0.6 \mathrm{MPa})$. These values suggest that damage should develop once the stress exceeds $\sigma_{\mathrm{C}}^{*}=2.25 \mathrm{MPa}$.

To compare this prediction with experiments, the onset of damage is defined as the cycle at which at least $50 \%$ of the samples have begun to lose mass (Supplementary Fig. 4). Figure 4 shows that, at temperatures from 3 to $25^{\circ} \mathrm{C}$, this systematically happens (filled symbols) in the first cycle for which the stress exceeds the predicted value. This graph also explains Price's observation ${ }^{32}$ that Portland limestone does not fail at $30^{\circ} \mathrm{C}$, as we find that the maximum value of $\sigma^{*}$ at that temperature is only 2.0 MPa (discontinuous line). To further check our damage prediction criterion, an additional experiment was performed using a more dilute solution $(2 \%(\mathrm{w} / \mathrm{w}))$ at $10^{\circ} \mathrm{C}$ (Supplementary Fig. 5). In this case, instead of having damage initiated between the first and second cycles, it begins between the second and the third cycles, which matches the theoretical prediction.

\section{Discussion}

By allowing systematic variation of the crystallization pressure and the volume fraction of pores filled with salt, the selected experiments establish a damage failure criterion based on strain energy. In our experiments, the initiation of damage is determined on the basis of the initiation of mass loss. Knowledge of the accumulated amount of salts and the crystallization pressure led to reliable prediction of the onset of damage (also highly reproducible, as shown in Supplementary Figs 6-9). This failure criterion has been validated using strength data obtained from tests in which the sample fails from the largest flaw that is present. Therefore, it predicts the threshold for failure of flaws of that size. As the stress increases in succeeding cycles, smaller and smaller flaws will grow and cause additional damage. Such small flaws may progressively grow from cycle to cycle owing to fatigue until they are critical and also contribute in failure.

This represents the first direct and demonstrated prediction of the onset of damage due to salt crystallization. Of course, conditions in the field are far more complicated than the test we have analysed, with salts entering via rising damp, reactions with atmospheric pollution, deposition of marine salts or microbial activity, and water entering from the soil or precipitation. This means that prediction of damage for a monument requires consideration of the transport processes that bring water and salt to the pores. The complexity of achieving such a prediction is probably one of the reasons why some authors have questioned the usefulness of single-variable controlled experiments in being able to predict outcomes of real-world weathering ${ }^{55,56}$. However, while single parameter studies are certainly not sufficient, our study demonstrates how fundamental principles can be used to predict the onset of damage, and emphasizes the importance of transport modelling for achieving similar predictions in real-life exposure.

\section{Methods}

Mass measurements. On the lines of the measurements obtained at the British Research Establishment and reported by Price ${ }^{32}$, we carried out measurements of mass changes on $2 \times 2 \times 2 \mathrm{~cm}^{3}$ samples of Portland limestone (purchased from Portland Stone Firms Ltd., Portland, Dorset, UK) as a function of cycles of vacuum impregnation with $6.1 \%(\mathrm{w} / \mathrm{w})$ sodium sulfate solution and drying at $105^{\circ} \mathrm{C}(18 \mathrm{~h}$ long). In a Vötsch VC 4060 climatic chamber (Vötsch Industrietechnik GmbH, Balingen-Frommern, Germany), after $2 \mathrm{~h}$ of equilibration at the impregnation temperature $\left(3,10,20\right.$ or $\left.25^{\circ} \mathrm{C}\right)$ and $0.5 \mathrm{~h}$ of evacuation in a glass desiccator, samples were impregnated for $1 \mathrm{~h}$. The stone was cut from several blocks and the resulting samples were randomized to eliminate possible effects of spatial variability, even though this stone is known to be very homogenous ${ }^{54}$.

Mass measurements were carried out with a Mettler-Toledo PM4000 technical balance (Mettler-Toledo $\mathrm{GmbH}$, Greifensee, Switzerland) after letting the samples equilibrate in a climatic room at $20^{\circ} \mathrm{C}$ and $50 \%$ relative humidity for $2 \mathrm{~h}$. When a higher precision was necessary, a Mettler-Toledo NewClassic MS-204S analytical balance was used.

Between 3 and $25^{\circ} \mathrm{C}$, a solution with a sodium sulfate concentration of $6.1 \%$ (w/ w) corresponds to a concentration ${ }^{57}$ of $0.0645 \pm 0.0001 \mathrm{~g} \mathrm{ml}^{-1}$, whereas the one at $2 \%(\mathrm{w} / \mathrm{w})$ corresponds to a concentration of $0.02036 \pm 0.00003 \mathrm{~g} \mathrm{ml}^{-1}$.

Mechanical measurements. The direct tensile strength tests were performed on a $10-\mathrm{kN}$ universal testing machine 1454 by Zwick GmbH (Ulm, Germany) on six stone cylinders with a diameter of $2 \mathrm{~cm}$, which were previously vacuum impregnated for $1 \mathrm{~h}$ with a $6.1 \%(\mathrm{w} / \mathrm{w})$ sodium sulfate solution at $20^{\circ} \mathrm{C}$. The used load cell was a $10-\mathrm{kN}$ one. The software for data acquisition was TestXpert II by Zwick.

In addition, we performed indirect tensile tests using the Brazilian test on $2 \times 2 \times 2 \mathrm{~cm}^{3}$ stone cubes with the same equipment used for the tensile strength tests. The value of $5.8 \pm 0.4 \mathrm{MPa}$ (obtained with five samples) is about two times larger than direct tensile strength tests, which is in agreement with what is reported in literature $\mathrm{e}^{58}$

Reproducibility. At each temperature we used groups of six to eight samples (six at 10,20 and $25^{\circ} \mathrm{C}$; eight at $3{ }^{\circ} \mathrm{C}$ ). These were cut from the different blocks and randomized to cancel out the possible effect of spatial distribution. In addition, to assess the reproducibility of this procedure we tested two additional groups of six samples, one at $3{ }^{\circ} \mathrm{C}$ and one at $20^{\circ} \mathrm{C}$. Results show a very good reproducibility between sample sets in terms of average mass loss and fraction of damaged samples, as shown in Supplementary Figs 6-9.

\section{References}

1. Mortensen, H. Die 'Salzsprengung' und ihre Bedeutung für die Regionalklimatische Gliederung der Wüsten. Petermanns Geogr. Mitt. 79, 130-135 (1933).

2. Wellman, H. W. \& Wilson, A. T. Salt weathering, a neglected geological erosive agent in coastal and arid environments. Nature 205, 1097-1098 (1965).

3. Goudie, A. S. \& Viles, H. A. Salt Weathering Hazards (John Wiley \& Sons, Ltd, 1997).

4. Espinosa-Marzal, R. M. \& Scherer, G. W. Advances in understanding damage by salt crystallization. Acc. Chem. Res. 43, 897-905 (2010).

5. Siedel, H. \& Siegesmund, S. in Stone in Architecture. (eds Siegesmund, S. \& Snethlage, R.) 349-414 (Springer, 2014).

6. Vergès-Belmin, V. in Environmental Geomechanics (eds Schrefler, B. \& Delage, P.) 201-245 (John Wiley \& Sons Inc., 2013).

7. Tsui, N., Flatt, R. J. \& Scherer, G. W. Crystallization damage by sodium sulfate J. Cult. Herit. 4, 109-115 (2003).

8. Flatt, R. J. \& Scherer, G. W. Thermodynamics of crystallization stresses in DEF. Cem. Concr. Res. 38, 325-336 (2008).

9. Alonso, E. E. \& Ramon, A. Massive sulfate attack to cement-treated railway embankments. Géotechnique 63, 857-870 (2013). 
10. Kunther, W., Lothenbach, B. \& Scrivener, K. L. On the relevance of volume increase for the length changes of mortar bars in sulphate solutions. Cem. Concr. Res. 46, 23-29 (2013).

11. Serafeimidis, K. \& Anagnostou, G. On the time-development of sulphate hydration in anhydritic swelling rocks. Rock Mech. Rock Eng. 46, 619-634 (2013).

12. Sass, I. \& Burbaum, U. Damage to the historic town of Staufen (Germany) caused by geothermal drillings through anhydrite-bearing formations. Acta Carsologica 39, 233-245 (2010)

13. Anagnostou, G., Pimentel, E. \& Serafeimidis, K. Swelling of sulphatic claystones - some fundamental questions and their practical relevance/Quellen von sulfatführenden Tonsteinen - Themen der Grundlagenforschung und ihre praktische Bedeutung. Geomech. Tunn. 3, 567-572 (2010).

14. Taber, S. The growth of crystals under external pressure. Am. J. Sci. s4-41, 532-556 (1916).

15. Correns, C. W. \& Steinborn, W. Experimente zur Messung und Erklärung der sogenannten Kristallisationskraft. Z. Kristallogr. 101, 117-133 (1939).

16. Evans, I. S. Salt crystallization and rock weathering: a review. Rev. Géomorph. Dyn. 19, 153-177 (1969).

17. Rodriguez-Navarro, C. \& Doehne, E. Salt weathering: influence of evaporation rate, supersaturation and crystallization pattern. Earth Surf. Process Landf. 24, 191-209 (1999).

18. Malin, M. C. Salt weathering on Mars. J. Geophys. Res. 79, 3888-3894 (1974).

19. Clark, B. C. \& Van Hart, D. C. The salts of Mars. Icarus 45, 370-378 (1981).

20. Rodriguez-Navarro, C. Evidence of honeycomb weathering on Mars. Geophys. Res. Lett. 25, 3249-3252 (1998).

21. Fitzner, B., Heinrichs, K. \& La Bouchardiere, D. Weathering damage on Pharaonic sandstone monuments in Luxor-Egypt. Build. Environ. 38, 1089-1103 (2003)

22. Paradise, T. R. Petra revisited: an examination of sandstone weathering research in Petra, Jordan. Geol. Soc. Am. Spec. Pap. 390, 39-49 (2005).

23. Heinrichs, K. Diagnosis of weathering damage on rock-cut monuments in Petra, Jordan. Environ. Geol. 56, 643-675 (2008).

24. Stefanis, N.-A., Theoulakis, P. \& Pilinis, C. Dry deposition effect of marine aerosol to the building stone of the medieval city of Rhodes, Greece. Build Environ. 44, 260-270 (2009).

25. Mancinelli, F. in The Conservation of Wall Paintings: Proceedings of a Symposium Organized by the Courtauld Institute of Art and the Getty Conservation Institute, London, July 13-16, 1987. (ed. Cather, S.) 57-66 (Getty Conservation Institute, 1991).

26. Preusser, F. in The Conservation of Wall Paintings: Proceedings of a Symposium Organized by the Courtauld Institute of Art and the Getty Conservation Institute, London, July 13-16, 1987. (ed. Cather, S.) 1-12 (Getty Conservation Institute, 1991).

27. Wüst, R. A. J. \& Schlüchter, C. The origin of soluble salts in rocks of the Thebes mountains, Egypt: the damage potential to ancient Egyptian wall art. J. Archaeol. Sci. 27, 1161-1172 (2000).

28. Benito, G., Machado, M. J. \& Sancho, C. Sandstone weathering processes damaging prehistoric rock paintings at the Albarracin Cultural Park, NE Spain. Environ. Geol. 22, 71-79 (1993).

29. Pope, G. A., Meierding, T. C. \& Paradise, T. R. Geomorphology's role in the study of weathering of cultural stone. Geomorphology 47, 211-225 (2002).

30. Goudie, A. Further experimental investigation of rock weathering by salt crystallisation and other mechanical processes. Z. Geomorphol. Suppl. 21, 1-12 (1974).

31. Scherer, G. W. Crystallization in pores. Cem. Concr. Res. 29, 1347-1358 (1999).

32. Price, C. A. in International Symposium: Deterioration and Protection of Stone Monuments 3.6, 1-23 (UNESCO-RILEM, 1978).

33. Commission 25-PEM Protection et érosion des monuments. Recommended tests to measure the deterioration of stone and to assess the effectiveness of treatment methods. Materr. Constr. 13, 175-253 (1980).

34. C09 Committee. Test Method for Soundness of Aggregates by Use of Sodium Sulfate or Magnesium Sulfate (ASTM International, 2013).

35. De Thury, H. Expériences faites à l'Inspection générale des carrières de Paris sur les pierres d'appareil, sur les marbres, le briques et les mortiers antiques et modernes. Ann. Chim. Phys. 38, 160-192 (1828).

36. Schiro, M., Ruiz-Agudo, E. \& Rodriguez-Navarro, C. Damage mechanisms of porous materials due to in-pore salt crystallization. Phys. Rev. Lett. 109, 265503 (2012).

37. Rijniers, L. A., Huinink, H. P., Pel, L. \& Kopinga, K. Experimental evidence of crystallization pressure inside porous media. Phys. Rev. Lett. 94, 075503 (2005).

38. Flatt, R. J. Salt damage in porous materials: how high supersaturations are generated. J. Cryst. Growth 242, 435-454 (2002).

39. Steiger, M. Crystal growth in porous materials-I: the crystallization pressure of large crystals. J. Cryst. Growth 282, 455-469 (2005).
40. Espinosa Marzal, R. M. \& Scherer, G. W. Crystallization of sodium sulfate salts in limestone. Environ. Geol. 56, 605-621 (2008).

41. Steiger, M. \& Asmussen, S. Crystallization of sodium sulfate phases in porous materials: the phase diagram $\mathrm{Na}_{2} \mathrm{SO}_{4}-\mathrm{H}_{2} \mathrm{O}$ and the generation of stress. Geochim. Cosmochim. Acta 72, 4291-4306 (2008).

42. Rodriguez-Navarro, C., Doehne, E. \& Sebastian, E. How does sodium sulfate crystallize? Implications for the decay and testing of building materials. Cem. Concr. Res. 30, 1527-1534 (2000).

43. Linnow, K., Zeunert, A. \& Steiger, M. Investigation of sodium sulfate phase transitions in a porous material using humidity- and temperature-controlled X-ray diffraction. Anal. Chem. 78, 4683-4689 (2006).

44. Oswald, I. D. H. et al. In situ characterization of elusive salt hydrates-the crystal structures of the heptahydrate and octahydrate of sodium sulfate. J. Am. Chem. Soc. 130, 17795-17800 (2008).

45. Derluyn, H., Saidov, T. A., Espinosa-Marzal, R. M., Pel, L. \& Scherer, G. W. Sodium sulfate heptahydrate I: the growth of single crystals. J. Cryst. Growth 329, 44-51 (2011).

46. Saidov, T. A. Sodium Sulfate Heptahydrate in Weathering Phenomena of Porous Materials. PhD thesis (Eindhoven University of Technology, 2012).

47. Rijniers, L. A., Pel, L., Huinink, H. P. \& Kopinga, K. Salt crystallization as damage mechanism in porous building materials-a nuclear magnetic resonance study. Magn. Reson. Imaging 23, 273-276 (2005).

48. Rijniers, L. A. Salt Crystallization in Porous Materials: an NMR Study. PhD thesis (Eindhoven University of Technology, 2004).

49. Hamilton, A., Hall, C. \& Pel, L. Sodium sulfate heptahydrate: direct observation of crystallization in a porous material. J. Phys. Appl. Phys. 41, 212002 (2008).

50. Espinosa-Marzal, R. M. \& Scherer, G. W. Mechanisms of damage by salt. Geol. Soc. Lond. Spec. Publ. 331, 61-77 (2010).

51. Coussy, O. Deformation and stress from in-pore drying-induced crystallization of salt. J. Mech. Phys. Solids 54, 1517-1547 (2006).

52. Fabre, D. \& Gustkiewicz, J. in Poromechanics: Proceedings of the first Biot Conference on Poromechanics. (eds Thimus, J.-F. et al.) 561-566 (Balkema, 1998).

53. Espinosa-Marzal, R. M., Hamilton, A., McNall, M., Whitaker, K. \& Scherer, G. $\mathrm{W}$. The chemomechanics of crystallization during rewetting of limestone impregnated with sodium sulfate. J. Mater. Res. 26, 1472-1481 (2011).

54. Kimber, O. G., Allison, R. J. \& Cox, N. J. Mechanisms of failure and slope development in rock masses. T. I. Brit. Geogr. 23, 353-370 (1998).

55. Smith, B. J., Turkington, A. V. \& Curran, J. M. Urban stone decay: the great weathering experiment? Geol. Soc. Am. Spec. Pap. 390, 1-9 (2005).

56. Viles, H. A. Can stone decay be chaotic? Geol. Soc. Am. Spec. Pap. 390, 11-16 (2005).

57. Chen, C.-T. A., Chen, J. H. \& Millero, F. J. Densities of sodium chloride, magnesium chloride, sodium sulfate, and magnesium sulfate aqueous solutions at $1 \mathrm{~atm}$ from 0 to $50{ }^{\circ} \mathrm{C}$ and from 0.001 to $1.5 \mathrm{~m}$. J. Chem. Eng. Data 25, 307-310 (1980).

58. Siegesmund, S. \& Dürrast, H. in Stone in Architecture. (eds Siegesmund, S. \& Snethlage, R.) 97-224 (Springer, 2014)

\section{Acknowledgements}

We would like to acknowledge discussions with Rosa Espinosa-Marzal, in particular on the subject of using poromechanics in salt crystallization problems. Robert J. Allison is kindly acknowledged for the information provided about the mechanical properties of Portland limestone. Heinz Richner's and Giulia Giuntoli's technical assistance is also gratefully acknowledged. We are thankful to Ena Lloret Kristensen and Fulvio Caruso for the support in the elaboration of Fig. 2.

\section{Author contributions}

R.J.F., G.W.S. and F.C. designed the research. F.C. and A.M.A.S. performed the research. All the authors contributed in analysing the data and writing the paper.

\section{Additional information}

Supplementary Information accompanies this paper at http://www.nature.com/ naturecommunications

Competing financial interests: The authors declare no competing financial interests.

Reprints and permission information is available online at http://npg.nature.com/ reprintsandpermissions/

How to cite this article: Flatt, R. J. et al. Chemomechanics of salt damage in stone. Nat. Commun. 5:4823 doi: 10.1038/ncomms5823 (2014). 